\title{
Association of frailty in hospitalized and institutionalized elderly in the community-dwelling
}

\author{
Associação da fragilidade em idosos internados e institucionalizados na comunidade \\ Asociación de la fragilidad en ancianos internados e institucionalizados en la comunidad
}

\section{Suzele Cristina Coelho Fabrício-Wehbe', Rosalina Aparecida Partezani Rodrigues', Vanderlei Jose Haas", Jack Roberto Silva Fhon', Marina Aleixo Diniz'}

' Universidade de São Paulo, Ribeirão Preto College of Nursing. Ribeirão Preto, São Paulo, Brazil. "Universidade Federal do Triângulo Mineiro, Postgraduate Program Stricto Sensu in Health Care. Uberaba, Minas Gerais, Brazil.

How to cite this article:

Fabrício-Wehbe SCC, Rodrigues RAP, Haas VJ, Fhon JRS, Diniz MA. Association of frailty in hospitalized and institutionalized elderly in the community-dwelling. Rev Bras Enferm [Internet]. 2016;69(4):644-9.

DOI: http://dx.doi.org/10.1590/0034-7167.2016690411i

Submission: 08-21-2015 Approval: 03-23-2016

\begin{abstract}
Objective: to investigate the association between frailty with hospitalization and institutionalization in a follow-up study of elderly residents. Method: the follow-up study was performed in 2008 and 2013 with elderly of both genders, aged 65 years and older who were living in the community-dwelling. The sampling procedure performed was probabilistic, with dual-stage clustering. In 2008, 515 elderly people were interviewed and, in 2013, 262. We used the socioeconomic and demographic data, self-reported morbidity, specific data of hospitalization and institutionalization. Frailty was measured by the Edmonton Frail Scale (EFS), and functional capacity through the Functional Independence Measure. Results: we found the mean gross EFS score was higher among resident elderly who were hospitalized and institutionalized and was statistically significant in both investigated years. Conclusion: the confirmation of association between frailty and hospitalization and institutionalization reinforces the importance of the subject, and highlights frailty as an important tool for risk estimates for these adverse events.

Descriptors: Frail Elderly; Aged; Hospitalization; Institutionalization; Geriatric Nursing.
\end{abstract}

\section{RESUMO}

Objetivo: investigar a associação entre a fragilidade e a internação e institucionalização em um estudo de acompanhamento de residentes idosos. Método: o estudo de acompanhamento foi realizado em 2008 e 2013 com idosos de ambos os sexos, com 65 anos ou mais de idade, que viviam na comunidade. O procedimento de amostragem realizado foi probabilístico, com agrupamento em dois estágios. Foram entrevistados 515 idosos em 2008, e 262 em 2013. Dados socioeconômicos e demográficos, morbidade relatada pelos mesmos, e dados específicos de internação e institucionalização foram utilizados. A fragilidade foi medida pela escala Edmond Frail Scale (EFS), e a capacidade funcional pela escala Functional Independence Measure (FIM). Resultados: A média da pontuação EFS foi maior entre os residentes idosos que foram internados e hospitalizados, e foi estatisticamente significativa nos dois anos investigados. Conclusão: A confirmação da associação entre a fragilidade e a internação e institucionalização reforça a importância do tema e enfatiza a fragilidade como um instrumento importante na avaliação dos riscos para esses eventos adversos.

Descritores: Idoso Frágil; Idoso; Hospitalização; Institucionalização; Enfermagem Geriátrica.

\section{RESUMEN}

Objetivo: investigar la asociación entre la fragilidad y la internación e institucionalización, en un estudio de acompañamiento de residentes ancianos. Método: el estudio de acompañamiento fue realizado en 2008 y 2013, con ancianos de ambos sexos, de 65 años o más, los cuales vivían en la comunidad. El procedimiento de muestreo realizado fue probabilístico, con agrupamiento en dos etapas. Fueron entrevistados 512 ancianos en 2008 y 262 en 2013. Datos socioeconómicos y 
demográficos, morbilidad relatada por los mismos y datos específicos de internación e institucionalización han sido utilizados. La fragilidad fue medida por la escala Edmond Frail Scale (EFS) y la capacidad funcional por la escala Functional Independence Measure (FIM). Resultados: El promedio de la puntuación EFS fue mayor entre los residentes ancianos que fueron internados y hospitalizados, siendo estadísticamente significativa en los dos años investigados. Conclusión: La confirmación de la asociación entre la fragilidad y la internación e institucionalización refuerza la importancia del tema y enfatiza la fragilidad como un instrumento importante en la evaluación de los riesgos para estos eventos adversos.

Descriptores: Anciano Frágil; Anciano; Hospitalización; Institucionalización; Enfermería Geriátrica.

\section{INTRODUCTION}

Conducting studies to investigate how frailty develops, how it can be safely detected, prevented, and what factors may be associated with it is essential to understanding this geriatric syndrome ${ }^{(1)}$.

A group of experts from six international centers (North American and European), who study aging and frailty, released a consensus on the definition of frailty that suggests it is an important medical syndrome, caused by multiple factors, characterized by decreased strength, endurance and physiological function, which increases the vulnerability of a person for greater dependency and/or death ${ }^{(2)}$.

For some authors, this multifactorial cause may be linked to the interaction of biological, psychological, cognitive, social and environmental issues experienced over time, with the potential to prevent and treat symptoms, especially when it is identified early ${ }^{(3-4)}$. It is this approach that is used within the Edmonton Frail $\mathrm{Scale}^{(3)}$, validated in Brazil(5-6), and which was used by this study.

Among experts in the area of aging, it is undisputed that this geriatric syndrome is associated with adverse health outcomes such as functional decline, dependence, recurrent falls, fractures, institutionalization, hospitalization and mortality ${ }^{(7-9)}$. Some studies show that frailty can be a predictive measure of immobility, the inability to develop basic and instrumental activities of daily living, institutionalization, hospitalization and death $^{(10-15)}$. Frequent hospitalization has been an indicator for frailty. Some models proposed for frailty screening use hospitalization as an adverse outcome $\mathrm{e}^{(3-17)}$.

A recent publication highlighted the existence of 13 longitudinal studies that identified the association between frailty and some adverse event, especially death and disability. There was a paucity of publications specifically on the association between frailty and hospitalization and institutionalization ${ }^{(18)}$. Thus, this relationship has not been clearly determined.

This study aims to analyze the association between frailty and hospitalization and institutionalization, in the tracking of elderly residents.

\section{METHOD}

\section{Ethical aspects}

The project was approved by the Ethics and Research Committee of Ribeirão Preto School of Nursing, University of São Paulo (EERP/USP). The Terms of Free and Informed Consent were read and signed in duplicate by the elder and/or the caregiver/family member of the elder, before interviews started.

\section{Design and period}

This is a follow-up study performed in 2008 and 2013, in Ribeirão Preto, São Paulo, Brazil, with elderly aged 65 years or older, living in the community.

\section{Population and sample}

The sampling procedure performed was probabilistic, using dual-stage clustering. At first, the census sector was considered as a Primary Sampling Unit. Then, a fixed number of households was visited to ensure self-weighting of the sample, with streets and blocks where this search process was started being drawn. At least 110 households in each sector were visited.

In 2008, 515 elderly were interviewed. In the first semester of 2013, these elderly were first contacted by telephone to schedule the second visit for interviews.

In 2013, the issue of sample loss was included in the study design, however it was higher than expected. The deaths totaled $24.7 \%$ and losses due to changes of address, refusal, institutionalization, and absence of the elderly at home (after three visits) totaled $24.4 \%$. Thus, in 2013, for the analysis of the association between frailty and hospitalization, the sample consisted of 262 elderly and for analysis of the association between frailty and institutionalization, of 271 elderly was considered.

\section{Study protocol}

The cognitive assessment was performed through the Mini Mental State Examination (MMSE) ${ }^{(19-20)}$. When the elderly had a score indicative of cognitive impairment, the presence of a family member/caregiver was requested to confirm the data during the interview.

For the dependent variables institutionalization and hospitalization, data were obtained from the elderly, family members and/or caregivers. For institutionalization, only the data from 2008 were considered. The date, place and reason for institutionalization were investigated. Regarding hospitalization, the date, number of hospitalizations, length of stay, and reason for each hospitalization in the previous five years were investigated.

Personal, socioeconomic and self-reported morbidity information was collected through an instrument developed by the Center for Research in Geriatric and Gerontology Nursing/ USP (NUPEGG). For the analysis, the total number of selfreported illnesses (0-24) was considered.

The Edmonton Frail Scale (EFS) ${ }^{(3-6)}$, evaluates nine domains represented by 11 items, including cognitive, general health status, functional independence, social support, medication use, nutrition, mood, continence and functional performance. 
The maximum score is 17 , which represents the highest level of frailty. For the analysis, we used the raw EFS score (0-17).

The Functional Independence Measure (FIM) aims to measure the degree of care required by the patient with disabilities to perform motor and cognitive tasks ${ }^{(21)}$. Its total score ranges from 18 to 126 points, and lower values indicate a greater functional dependence. For the analysis, the FIM raw score was considered.

\section{Analysis of results}

For the descriptive analysis of numerical variables, measures of central tendency and dispersion were used, and proportions were used for categorical variables.

In order to determine the association between the variables with hospitalization and institutionalization, the Fisher's exact test was used. For the income variables, the raw EFS score and raw FIM score, the Mann-Whitney test was used. Logistic regression models were adjusted for the hospitalization variables, and another for institutionalization. Adjustments were made considering all the independent variables and removing non-significant variables. Next, the individual adjustment was tested for each variable and the significant ones were investigated. The dependent variable in both cases is their occurrence. The selection of the best model, if there was more than one candidate model, was performed using the Akaike Information Criterion (AIC). According to this criterion, the lower the value, the better the fit of the model. In all analyses, a significance level of $5 \%$ (alpha $=0.05$ ) was considered.

\section{RESULTS}

\section{Regarding hospitalization}

Among the 262 elderly respondents in both years, the majority were female $(66.4 \%)$, with a mean age of 75 years $(\mathrm{SD}=7.2)$ in 2008 and 79 years $(\mathrm{SD}=6.3)$ in 2013 . Of these, $56.1 \%$ had $1-5$ years of education and there was a predominance of unmarried elderly (50.8\%), with an income of up to $\mathrm{R} \$ 1,000.00$ (2008, $72.5 \%$; 2013, 60.7\%). Among the self-reported illnesses, there was a predominance of hypertension $(63.0 \%)$, among others. During this period, $98(37.4 \%)$ participants reported having been hospitalized. The reasons were specific, such as surgery $(50.0 \%)$, emergency care $(28.6 \%)$, clinical treatment $(21.4 \%)$, exam needs $(6.1 \%)$. It is also noteworthy that there was more than one reason for hospitalization. However, $2.0 \%$ of the elderly were unable to provide information about these.

There was no statistical significance in the association of hospitalization with sociodemographic variables either in 2008 or in 2013.

For the analysis of the income variable, amounts in reais (Brazilian currency) according to mean tests were considered. In 2008, the mean income of the elderly who were not hospitalized was greater than the mean income of the elderly who

Confidence interval were not hospitalized, statistically significant only in 2008. The mean raw EFS score was higher among the elderly who were hospitalized, with statistical significance in both years. In the analysis of the raw FIM score, the mean values were higher among those not hospitalized, and were statistically significant in both years. The total mean of self-reported illnesses was higher among those not hospitalized, and it was statistically significant only in 2013.

In the logistic regression for hospitalization, considering all the independent variables, the raw EFS score and the number of self-reported illnesses in 2013 were statistically significant. In the individual analysis of the variables, the raw EFS score, raw MIF score, and the number of illnesses were statistically significant in both years. However, when testing them together, only the EFS score and the number of illnesses in 2013 remained significant.

Using the AIC criterion as a reference, the model with EFS scores and number of illnesses in 2013 had the best fit. Thus, according to the odds ratio, for each increase of one in the frailty scale of 2013, the chance of occurrence of hospitalization increases 1.24 times (given the same number of illnesses). For each extra illness that the elderly might have had in 2013, the chance of occurrence of hospitalization increased by 0.85 , the total number of illnesses then being a protective factor (Table 1).

Notes: EFS - Edmonton Frail Scale; $S E=$ Standard Error; $Z=$ Normal Curve; OR - Odds ratio; $\mathrm{Cl}$ and total morbidity reported in 2013 by elderly residents

$\begin{array}{lcccccc}\text { (Intercept) } & 1.725 & 1.514 & 1.139 & 0.254 & - & - \\ \text { EFS Raw Score 2013 } & 0.217 & 0.056 & 3.864 & <\mathbf{0 . 0 0 1} & 1.243 & (1.116-1.393) \\ \text { Illnesses 2013 } & -0.159 & 0.061 & -2.601 & \mathbf{0 . 0 0 9} & 0.852 & (0.751-0.957)\end{array}$

\section{Regarding institutionalization}

This analysis considered 271 elderly in 2013. Of these, nine $(3.3 \%)$ were admitted to long-term care institutions for the elderly, of which the majority were female $(8 ; 88.9 \%)$, mean age 80.4 years $(=9.7)$, younger elderly $(5 ; 55.6 \%)$, widowed $(4 ; 44.4 \%)$, with $1-5$ years of education $(5 ; 55.5 \%)$, and an income between $\mathrm{R} \$ 0$ - $\$ 1,000$ (7; 77.8\%). The selfreported illnesses included: impaired vision (6; 66.7\%), among others. Most of the elderly were considered dependent according to the FIM $(5 ; 55.6 \%)$. The main reason for the institutionalization of the elderly, reported by family members, was the emergence of functional dependence and cognitive impairment. There was no statistically significant association between institutionalization with gender, age, marital status or education (Table 2). 
Table 2 - $\quad$ Fisher's exact test for long-term care institutionalization with the variables of sex, age, marital status and education in elderly residents interviewed in 2008

\begin{tabular}{|c|c|c|c|}
\hline \multirow[b]{2}{*}{ Variables } & \multicolumn{3}{|c|}{ Institutionalization } \\
\hline & $\begin{array}{c}\text { No } \\
\text { n (\%) }\end{array}$ & $\begin{array}{c}\text { Yes } \\
\text { n (\%) }\end{array}$ & $p$ value \\
\hline \multicolumn{4}{|l|}{ Sex } \\
\hline Male & $88(98.9)$ & $1(1.1)$ & 0.279 \\
\hline Female & $174(95.6)$ & $8(4.4)$ & \\
\hline \multicolumn{4}{|l|}{ Age } \\
\hline Younger elderly & $208(97.6)$ & $5(2.34)$ & 0.101 \\
\hline Older elderly & $54(93.1)$ & $4(6.89)$ & \\
\hline \multicolumn{4}{|l|}{ Marital status } \\
\hline With partner & $129(98.5)$ & $2(1.5)$ & 0.174 \\
\hline Without partner & $133(95.0)$ & $7(5.0)$ & \\
\hline $\begin{array}{l}\text { Education } \\
\text { Illiterate } \\
1 \text { to } 5 \text { years } \\
6 \text { to } 10 \text { years } \\
11 \text { years or more }\end{array}$ & $\begin{array}{c}46(97.87) \\
146(96.68) \\
29(93.54) \\
41(97.61)\end{array}$ & $\begin{array}{l}1(2.12) \\
5(3.31) \\
2(6.45) \\
1(2.38)\end{array}$ & 0.705 \\
\hline
\end{tabular}

Notes: Younger elderly (60 - 79 years old); Older elderly (80 years old or older); Fisher's exact test $p<0.05$.

According to the Mann-Whitney test, there was no association of the income variable with institutionalization $(p=0.904)$, but it was associated with the raw EFS score $(p=0.015)$ and FIM score $(p=0.046)$ (Table 3$)$.

In the logistic regression, considering all the variables described above in Tables 2 and 3, education (category 6 - 10 years) and the raw FIM score were statistically significant. However, when the variables were tested separately, age, raw score of frailty and the FIM showed statistical significance; when tested together, they were not statistically significant.

Thus, according to the AIC criterion, the individual models of age, raw score of EFS and FIM were compared. It was found that the FIM score had the lower AIC among the three models analyzed.
The Odds ratio analysis showed that for every point in the increase of the FIM scale in 2008, the elderly person's chance of being institutionalized decreased $6.3 \%$. Thus, the FIM is a protective factor.

\section{DISCUSSION}

In the analysis of the relationship between frailty and hospitalization and institutionalization, there was statistical significance, suggesting that frailty is a possible predictor of such events.

The absence of a universal criterion accepted by researchers to evaluate frailty prevents the comparison between different studies, because the publications use different instruments (Frailty Index, Cardiovascular Health Study, Armstrong Index, FI-CGA) ${ }^{(22-24)}$.

A systematic review, between 1990 and $2010^{(23)}$, investigated the association between geriatric syndromes (including frailty) and hospitalization and admission to long term care facilities, with various definitions of frailty. It found an increased risk of hospitalization and institutionalization among the frail elderly. In another study, $31.3 \%$ of the frail elderly reported being hospitalized, compared with $20.3 \%$ of non-frail, and both showed statistical significance ${ }^{(15)}$.

Frailty in the elderly can be considered a specific phenotype, a condition often characterized by the presence of clinically unstable conditions, accompanied by advanced age, severe cognitive disorders, loss of autonomy and critical socioeconomic conditions ${ }^{(25)}$. Multiple disorders, dementia and disabilities can both lead the elderly to frailty and cause worsening and aggravation of this state. Frail elderly may have multiple chronic diseases and/or significant physical or cognitive decline, requirements that select the candidate for multidimensional care ${ }^{(26)}$ leading to hospitalizations and admission to long-term care facilities for the elderly.

Research findings are in agreement with those found in a study conducted in Canada, with 1,066 residents 65 years or older, which investigated the adjusted risk of mortality, hospitalization and institutionalization in those categorized as frail and non-frail, based upon three different instruments of frailty and the Changes in Health, End-Stage Illness and Signs and

Table 3 - Mann Whitney's Test of long-term care institutionalization with the variables income and raw EFS score in elderly residents interviewed in 2008

\begin{tabular}{|c|c|c|c|c|c|c|c|c|c|}
\hline Variables & Hospitalization & Minimum & 1st Quartile & Median & Mean & 3rd Quartile & Maximum & SD & $p$ value \\
\hline \multirow{2}{*}{ Income } & No & 0.0 & 380.0 & 400.0 & 938.5 & 1100.0 & 10000.0 & 1.3 & 0.904 \\
\hline & Yes & 380.0 & 380.0 & 380.0 & 773.3 & 760.0 & 2400.0 & 719.0 & \\
\hline \multirow{2}{*}{ Raw EFS Score ${ }^{a}$} & No & 0.0 & 2.0 & 4.0 & 4.2 & 6.0 & 12.0 & 2.6 & 0.015 \\
\hline & Yes & 3.0 & 5.0 & 5.0 & 6.4 & 9.0 & 11.0 & 2.7 & \\
\hline \multirow{2}{*}{ Raw FIM Score ${ }^{b}$} & No & 51.0 & 119.0 & 123.0 & 120.3 & 125.0 & 126.0 & 8.7 & 0.046 \\
\hline & Yes & 55.0 & 90.0 & 102.0 & 100.8 & 125.0 & 126.0 & 27.4 & \\
\hline
\end{tabular}

Notes: Mann Whitney's Test p<0.05; EFS -Edmonton Frail Scale; High scores indicate frailty (0-17); FIM - Functional Independence Measure; a - High scores indicate independence (18-126); SD - Standard deviation 
Symptoms (CHESS) Scale. Over one year, 15.9\% of residents died, $39.8 \%$ were hospitalized at least once, and $19.1 \%$ moved into long-term care facilities. Despite the different stages of frailty, measured with different instruments, association between frailty, death, hospitalization and institutionalization were established. The authors report that residents with more severe levels of frailty are more likely to die, become hospitalized, and require institutionalization in long-term care facilities ${ }^{(22)}$.

A prospective cohort study involving 752 elderly, aged 75 years or older, to investigate the predictive validity of the frailty index based on the geriatric assessment (CGA-FI) found that the increase of values in the index was associated with the growth of the risk of death, institutionalization, and length of hospital stay ${ }^{(24)}$. With increased frailty, the risk rates for death and institutionalization also increase ${ }^{(12)}$. Three large prospective cohort studies have also shown this association, with worse outcomes among frail elderly ${ }^{(8,16)}$.

In a cross-sectional study with 331 institutionalized elderly of both sexes, 65 years or older, in two institutions in Spain, a prevalence of frailty attributes of $68.8 \%$ was determined. Frailty was also associated with age and female gender. Frail residents had a higher rate of dementia and increased the number of comorbidities ${ }^{(27)}$.

Studies have shown that frailty is associated with institutionalization in Canadian populations in the community and in institutionalized homes ${ }^{(4-28)}$. The elderly often have heterogeneous characteristics, with different rates of disability, comorbidities and multiple vulnerabilities.

Over a period of five years, both the raw EFS score and the FIM had statistical significance, which indicates the need for constant geriatric assessments throughout life.
Although there are a few studies on the subject, detection and treatment of frailty should be used to prevent disability, mobility decline, falls and death ${ }^{(27-28)}$, in addition to the reduction of hospitalization and institutionalization.

\section{CONCLUSION}

The analysis of hospitalization of the elderly showed an association between the EFS score and the number of morbidities in 2013. However, institutionalization had an association with the EFS and the FIM scores. At every FIM point that increased, the elderly person's chance of being institutionalized decreased $6.3 \%$, which demonstrated that functional independence is a protective factor.

The confirmation of association between frailty and hospitalization and institutionalization reinforces the importance of the subject, and highlights frailty as an important tool for risk estimates for these adverse events.

The longitudinal method allowed to establish a cause and effect relationship, which broadened the knowledge on hospitalization and institutionalization of frail elderly people, however there was the risk of losing participants in the second assessment, which was confirmed in the study.

Thus, we suggest other studies on the subject, especially multi-centric studies, including other states of the country, to prove this association with a greater sample of elderly people.

\section{FUNDING}

Study financed by Fundação de Amparo à Pesquisa do Estado de São Paulo.

\section{REFERENCES}

1. Clegg A, Young J, Iliffe S, Rikkert MO, Rikkert MO, Rockwood K. Frailty in elderly people. Lancet [Internet]. 2013[cited 2015 Mar 26];381(9868):752-62. Available from: http:// www.ncbi.nlm.nih.gov/pmc/articles/PMC4098658/pdf/ emss-59306.pdf

2. Morley JE, Vellas B, van Kan GA, Anker SD, Bauer JM, Bernabei $R$ et al. Frailty Consensus: a call to action. J Am Med Dir Assoc [Internet]. 2013[cited 2015 Apr 24];14(6):392-7. Available from: http://www.ncbi.nlm.nih.gov/pmc/articles/ PMC4084863/pdf/nihms589815.pdf

3. Rolfson DB, Majumdar SR, Tsuyuki RT, Tahir A, Rockwood K. Validity and reliability of the Edmonton Frail Scale. Age Ageing [Internet]. 2006[cited 2015 May 5];35(5):526-9. Available from: http://ageing.oxfordjournals.org/content/35/5/526. full.pdf + html

4. Rockwood K, Abeysundera MJ, Mitnitski A. How should we grade frailty in nursing home patients? J Am Med Dir Assoc [Internet]. 2007[cited 2015 May 6];8(9):595-603. Available from: http://www.jamda.com/article/S1525-8610(07) 00351-9/abstract

5. Fabrício-Wehbe SCC, Schiaveto FV, Vendrusculo TRP,
Haas VJ, Dantas RA, Rodrigues RA. Cross-cultural adaptation and validity of the Edmonton Frail Scale - EFS in a Brazilian elderly people. Rev Latino-Am Enfermagem [Internet]. 2009[cited 2015 Apr 18];17(6):1043-9. Available from: http://www.scielo.br/pdf/rlae/v17n6/18.pdf

6. Fabrício-Wehbe SCC, Cruz IR, Haas VJ, Diniz MA, Dantas RAS, Rodrigues RAP. Reproducibility of the Brazilian version of the Edmonton Frail Scale for elderly living in the community. Rev Latino-Am Enfermagem [Internet]. 2013[cited 2015 Apr 18];21(6):1330-6. Available from: http://www.scielo.br/pdf/rlae/v21n6/0104-1169rlae-0104-1169-2933-2371.pdf

7. Ferrucci L, Guralnik JM, Studenski S, Fried LP, Cutler GB Jr, Walston JD. Designing randomized, controlled trials aimed at preventing or delaying funcional decline and disability in frail, older persons: a consensus report. J Am Geriatr Soc [Internet]. 2004[cited 2015 May 22];52(4):625-34. Available from: http://onlinelibrary.wiley.com/doi/10.1111/j.153 2-5415.2004.52174.x/pdf

8. Ensrud KE, Ewing SK, Taylor BC, Flink HA, Stone KL, Cauley JA et al. Frailty and risk of falls, fracture, and mortality in older women: the study of osteoporotic fractures. J 
Gerontol A Biol Sci Med Sci [Internet]. 2007[cited 2015 Jan 26];62(7):744-51. Available from: http://biomedgerontolo gy.oxfordjournals.org/content/62/7/744.full.pdf

9. Cawthon PM, Marshall LM, Michael Y, Dam TT, Ensrud KE, Barrett-Connor $\mathrm{E}$ et al. Frailty in older men: prevalence, progression, and relationship with mortality. J Am Geriatr Soc [Internet]. 2007 [cited 2015 Jan 25];55(8):1216-23. Available from: http://onlinelibrary.wiley.com/doi/10.1111/j.153 2-5415.2007.01259.x/pdf

10. Fried LP, Ferrucci L, Darer J, Williamson JD, Anderson G. Untangling the concepts of disability, Frailty and comorbidity: implications for improved targeting and a care. J Gerontol Med Sci [Internet]. 2004[cited 2015 Jan 24];59(3):255-63. Available from: http://biomedgerontology.oxfordjournals.org/ content/59/3/M255.full.pdf + html

11. Jones DM, Song X, Rockwood K. Operationalizing a frailty index from a standardized comprehensive geriatric assessment. J Am Geriatr Soc[Internet]. 2004 [cited 2015 Jan 24];52(11):1929-33. Available from: http://onlinelibrary. wiley.com/doi/10.1111/j.1532-5415.2004.52521.x/pdf

12. Rockwood K, Song X, MacKnight C, Bergman H, Hogan DB, McDowell I etal. A global clinical measure of fitness and frailty in elderly people. CMAJ [Internet]. 2005[cited 2015 Mar 13]; 173(5):489-95. Available from: http://www.ncbi.nlm.nih.gov/ pmc/articles/PMC1188185/pdf/20050830s00025p489.pdf

13. Rockwood K, Mitnitski A, Song X, Steen B, Skoog I. Longterm risks of death and institutionalization of elderly people in relation to deficit accumulation at age 70. J Am Geriatr Soc [Internet]. 2006[cited 2015 Mar 13];54(6):975-9. Available from: http://onlinelibrary.wiley.com/doi/10.1111/j.15 32-5415.2006.00738.x/pdf

14. Bandeen-Roche K, Xue QL, Ferrucci L, Walston j, Guralnik JM, Chaves $\mathrm{P}$ et al. Phenotype of frailty: characterization in the women's health and aging studies. J Gerontol A Biol Sci Med Sci [Internet]. 2006[cited 2015 Apr 18];61(3):262-6. Available from: http://biomedgerontology.oxfordjournals.org/ content/61/3/262.full.pdf + html

15. Avila-Funes JA, Helmer C, Amieva $H$, Bargerger-Gateau P, Le Goff $M$, Ritchie $K$ et al. Frailty among communitydwelling elderly people in France: the three-city study. J Gerontol A Biol Sci Med Sci [Internet] 2008[cited 2015 Apr 23];63(10):1089-96. Available from: http://biomedgeronto logy.oxfordjournals.org/content/63/10/1089.full.pdf + html

16. Rockwood K, Howlett SE, Macknight C, Beattle BL, Bergman $\mathrm{H}$, Hérbert $\mathrm{R}$ et al. Prevalence, attributes, and outcomes of fitness and frailty in community-dwelling older adults: report from the Canadian study of health and aging. J Gerontol A Biol Sci Med Sci [Internet]. 2004[cited 2015 Apr 20];59(12):1310-7. Available from: http://biomedgerontolo gy.oxfordjournals.org/content/59/12/1310.full.pdf + html

17. Gobbens RJ, van Assen MA, Luijkx KG, Wijnen-Sponselee MT, Schols JM. Determinants of frailty. J Am Med Dir Assoc [Internet] 2010[cited 2015 May 21];11(5):356-64. Available from: http://www.ncbi.nlm.nih.gov/pubmed/20511103

18. Abizanda P, Romero L, Sánchez-Jurado PM, Martínez-Reig M, Gómez-Arnedo L, Alfonso SA. Frailty and mortality, disability and mobility loss in a Spanish cohort of older adults: the FRADEA Study. Maturitas [Internet]. 2013[cited 2015 May 20];74(1):54-60. Available from: http://dx.doi.org/10.1016/j. maturitas.2012.09.018
19. Bertolucci PHF, Brucki SMD, Campacci SR, Juliano Y. The Mini Mental State Exam in a general population. Impact of education. Arq Neuro-Psiquiatr [Internet]. 1994[cited 2015 Jan 24];52(1):1-7. Available from: http://www.scielo.br/pdf/ anp/v52n1/01.pdf

20. Brucki SMD, Nitrini R, Caramelli P, Bertolucci PHF, Okamoto $\mathrm{IH}$. Suggestions for utilization of the mini-mental state examination in Brazil. Arq Neuro-Psiquiatr [Internet] 2003. [cited 2015 Feb 20];61(3-B):777-81. Available from: http://www.scielo.br/pdf/anp/v61n3B/17294.pdf

21. Riberto M, Miyazaki MH, Jucá SSH, Sakamoto H, Potiguara $P$, Pinto $\mathrm{N}$ etal. Validation of the Brazilian version of the functional independence measure. Acta Fisiatr [Internet]. 2004[cited 2015 Jan 24];11(2):72-6. Available from: http://www.unifra. br/professores/anabonini/Valida $\%$ C3\%A7\%C3\%A30\%20 Brasileira\%20MIF.pdf

22. Hogan DB, Freiheit EA, Strain LA, Patten SB, Schmaltz HN, Rolfson D et al. Comparing frailty measures in their ability to predict adverse outcome among older residents of assisted living. BMC Geriatrics [Internet]. 2012[cited 2015 Mar 15];12:56. Available from: http://www.biomedcentral.com/ content/pdf/1471-2318-12-56.pdf

23. Wang SY, Shamliyan TA, Talley KM, Ramakrishnan R, Kane RL. Not just specific illness: Systematic review of the association of geriatric syndromes with hospitalization or nursing home admission. Arch Gerontol Geriatr [Internet]. 2013[cited 2015 Apr 11];57(1):16-26. Availablefrom: http://ac. els-cdn.com/S016749431300040X/1-s2.0-S0167494313000 40X-main.pdf? tid = feadc3ee-9218-11e5-aeb7-00000aacb3 $62 \&$ acdnat $=1448307355$ da59248d71727241df9de50971 $810 \mathrm{c} 9 \mathrm{e}$

24. Evans SJ, Sayers M, Mitnitski A, Rockwood K. The risk of adverse outcomes in hospitalized older patients in relation to a frailty index based on a comprehensive geriatric assessment. Age Ageing [Internet]. 2014 Jan [cited 2015 Apr 12];43(1):127-32. Available from: http://ageing.oxfordj ournals.org/content/43/1/127.full.pdf + html

25. Weiss CO. Frailty and chronic diseases in older adults. Clin Geriatr Med [Internet]. 2011[cited 2015 Mar 25];27(1):39-52. Available from: http://www.geriatric. theclinics.com/article/S0749-0690(10)00077-7/pdf

26. Martocchia A, Frugoni P, Indiano I, Tafaro L, Comite F, Amici A et al. Screening of frailty in elderly patients with disability by the means of Marigliano-Cacciafesta polypathology scale (MCPS) and Canadian Study of Health and Aging (CSHA) scales. Arch Gerontol Geriatr [Internet]. 2013 Mar [cited 2015 Mar 20];56(2):339-342. Available from: http://www.aggjourna I.com/article/S0167-4943\%2812\%2900230-0/abstract

27. González-Vaca J, de la Rica-Escuín M, Silva-Iglesias M, Arjonilla-García MD, Varela-Pérez R, Oliver-Carbonelli JL et al. Frailty in institutionalized older adults from Albacete. The FINAL study: rationale, design, methodology, prevalence and attributes. Maturitas [Internet]. 2014[cited 2015 May 12];77(1):78-84. Available from: http://www.scienced irect.com/science/article/pii/S0378512213003150

28. Freiheit EA, Hogan DB, Strain LA, Schmaltz HN, Patten SB, Eliasziw $\mathrm{M}$ et al. Operationalizing frailty among older residents of assisted living facilities. BMC Geriatrics [Internet]. 2011[cited 2015 May 22];11:23. Available from: http://www. biomedcentral.com/content/pdf/1471-2318-11-23.pdf 